\title{
Concomitant Medication Use End Date Time
}

National Cancer Institute

\section{Source}

National Cancer Institute. Concomitant Medication Use End Date Time. NCI Thesaurus. Code C83225.

The date and time a concomitant medication usage has concluded. 